\title{
Prenatal stress and infants' development: association with cortisol and leptin levels in cord blood and saliva
}

\author{
Ehsan Saboory ${ }^{1,2 *}$ iD, Soheila Rabiepoor ${ }^{3 *}$ iD, Maryam Abedi ${ }^{4}$ \\ 1. Zanjan Metabolic Diseases Research Center, Zanjan University of Medical Sciences, Zanjan, Iran \\ 2. Department of Physiology, Faculty of Medicine, Urmia University of Medical Sciences, Urmia, Iran \\ 3. Reproductive Health Research Center, Urmia University of Medical Sciences, Urmia, Iran \\ 4. Department of Midwifery, Urmia University of Medical Sciences, Urmia, Iran
}

\begin{abstract}
Introduction: Stressful events during pregnancy may affect cognitive and somatic development in infants and increase the risk of developmental disorders in future. This study aimed at assessing the correlation between prenatal stress with salivary cortisol and leptin levels with a focus on infant development.
\end{abstract}

Methods: In this prospective correlative study, 80 infants whose mothers were admitted to clinics during pregnancy were evaluated. The pregnant women were included during 24-28 weeks of pregnancy and assessed using the perceived stress scale until delivery. Following delivery, growth and development of infants were evaluated using the Ages and Stages Questionnaire (ASQ) at birth as well as 2, 4 and 6 months after birth. For assessing leptin and cortisol levels, cord blood and salivary samples were collected at birth and 6 months after birth, respectively.

Results: The mean perceived stress score (PSS) during pregnancy was associated with infant development and weight at 2 and 6 months of age, respectively. Moreover, there was a negative association between leptin level at 6 months of age and infant height at 2, 4 and 6 months after birth. Finally, a negative correlation was observed between cortisol level at 6 months of age and infant height at 2 months following birth.

Conclusion: The results indicated that the PSS of the mothers negatively correlated with the infants' growth, development and cortisol and leptin levels. Thus, prenatal stress probably affects growth and development in infancy through effects on the neuroendocrine system. Leptin might be an appropriate biomarker for determination of growth and development in infancy.

http://dx.doi.org/10.32598/ppj.24.1.70

\author{
Keywords: \\ Prenatal stress; \\ Development; \\ Leptin; \\ Cortisol; \\ Saliva
}

\author{
* Corresponding authors: \\ Ehsan Saboory; \\ Soheila Rabiepoor \\ Emails: \\ saboory@zums.ac.ir; \\ rabieipour.s@umsu.ac.ir \\ Tel: +98 (44) 32770698 \\ Received 12 July 2019; \\ Received in revised form 7 \\ December 2019; Accepted 14 \\ December 2019
}

\section{Introduction}

Early life stress may cause neuropsychiatric disorders in adulthood and impair health and neurodevelopment of organisms (HosseiniSharifabad and Sabahi, 2014). Studies suggest that maternal prenatal psychosocial stress not only can affect the mental health during childhood, but also contributes to mental disorders later in life (Oates, 2002). Other complications of prenatal stress (PS) in offspring include impaired function of hypothalamuspituitary-adrenal axis (HPA), depression symptoms in 
adolescence and development of asthma in children (Van den Bergh et al., 2005; Cookson et al., 2009). Moreover, according to studies, perturbations in the maternal environment are transferred to the embryo through placenta. Thus, defects of placenta may cause problems in offspring growth and development which can negatively affect brain maturation and mental capabilities (Bronson and Bale, 2016). PS may cause preterm labor which is a risk factor for cerebral palsy and learning disabilities and also results in intrauterine growth retardation (Black et al., 2013; Abedi et al., 2017). Studies conducted in England and Sweden estimated that prevalence of PS is about $33-37 \%$ and $5-7 \%$, respectively (Woods et al., 2010).

HPA axis is activated in response to stress, which can lead to an increase in blood cortisol level in long term (Kudielka et al., 2004). Previous studies reported high cortisol and corticosterone concentration long after parturition following maternal stress during pregnancy (Gholipoor et al., 2017; Saboory et al., 2019). In humans, cortisol is the main glucocorticoid following HPA-axis stimulation in blood and saliva (Taddio and Katz, 2005). Although accurate information is not available, particularly in children under six months of age, the mechanism of cortisol secretion varies with age, and also physical and environmental stresses can exacerbate its secretion (Zijlmans et al., 2013). Changes in blood cortisol can alter cortisol level in saliva and salivary cortisol is an indicator of blood free cortisol or active biological cortisol (Alpers et al., 2003; Kudielka et al., 2004). Assessing saliva cortisol is more beneficial than measuring it in serum or plasma as its sampling is cheaper and non-invasive (Adam and Kumari, 2009). Moreover, studies suggest that there is a positive relationship between stress and salivary cortisol levels (Vedhara et al., 2003).

Further, glucocorticoids and adrenocorticotrophic hormone (ACTH) provoke synthesis and secretion of leptin which affects adrenal function (Lee et al., 2007; Eftekhari et al., 2015). The effect of HPA-axis on leptin secretion is controversial (Nishii et al., 2006). After birth, the mean serum and placental leptin levels of infants correlate with their arm fat mass and birth weight, respectively (Briffa et al., 2015). Although numerous studies have been conducted on PS as well as on leptin and cortisol levels in neonates, the correlation between leptin and cortisol levels with stress during pregnancy and the effects of these hormones on neonatal development are still unknown. Therefore, this study aimed to assess the correlation between PS with salivary cortisol and leptin levels with a focus on introducing an appropriate biomarker for growth and development of infants.

\section{Materials and methods}

In this prospective correlative study, we randomly evaluated 80 infants younger than 6 months whose mothers were admitted (as regularly scheduled check-ups) to the Health Center No.1, Miandoab, West Azerbaijan Province, Iran, from March 2016 to March 2017. The sample size of the study was determined according to the sample size of a study conducted by Salari et al. (2013) considering correlation coefficient of 0.312 between stress score and cortisol level, significance level of 0.05 and power of $80 \%$. Inclusion criteria comprised $24-28$ weeks of pregnancy; singleton pregnancy; negative history of cardiovascular, renal, pulmonary, psychiatric and autoimmune diseases; negative history of diabetes during and prior to pregnancy and negative history of neuroleptic drugs consumption. Moreover, exclusion criteria encompassed unwillingness to be included in the study.

\section{Ethical approval}

All procedures were reviewed and approved by the Ethics Committee at the Urmia University of Medical Sciences, Urmia, Iran (IR.UMSU.RIC.1394;205). The procedures were consistent to the guidelines of Declaration of Helsinki (2008). Appropriate informed consent was obtained from all the cases.

At first, the perceived stress scale (PSS) was filled out for the cases and their demographic characteristics were obtained. Then, the cases were followed up every 4 weeks. The first follow-up was conducted on the weeks 28-32, the second one was done on the weeks 32-34 and finally the last follow-up was done in the labor room prior to delivery. In all these follow-ups, we filled out PSS for the cases. In the labor room, cord blood samples were collected in order to determine cortisol and leptin levels of the neonates. At birth as well as 2, 4 and 6 months after birth, we measured weight, head circumference and height of the infants and also assessed infants' development using the Ages and Stages 
Questionnaire (ASQ). At 6 months of age, approximately $3 \mathrm{ml}$ of infants' saliva were collected between 9 and $11 \mathrm{am}$. The mothers were asked not to breastfeed their infants at least one hour prior to sampling. Then, the samples (both saliva and blood) were centrifuged at $1000 \mathrm{~g}$ for $10 \mathrm{~min}$. Finally, cortisol (DiaMetra, Italy) and leptin (BioVendor, Czech Republic) levels were checked using the ready to use ELISA kit.

\section{Tools}

1. Cohen's Perceived Stress Scale (PSS): it was firstly designed by Cohen et al. in 1983. PSS consists of 14 items evaluating thoughts, emotions and perceived general stress of people in the past. Scaling is according to 5-point Likert scale including never (0), almost never (1), sometimes (2), often (3) and almost always (4). The lowest point possible is 0 and the highest is 56 . Higher score indicates higher perceived stress (Cohen et al., 1983).

2. For evaluating infant development at 2 months after birth, we used a developmental status checklist designed by the Ministry of Health, Islamic Republic of Iran. These checklists are currently used in health centers and are according to the questionnaire of infant developmental status filled out using parents' expressions. The questionnaire consists of 5 items including smiling, making noise, getting calm with mother's voice, using fingers and 45-degree head elevation. Possible answers include yes and no and in case of negative answer, the infant is admitted to higher levels of the health system for further investigation.

3. The Ages and Stages Questionnaire (ASQ): this questionnaire evaluates developmental status of children aged 4-60 months in 19 different age groups and 5 developmental areas including gross movement, fine movement, communication, solving problem and personal-social skills by comparison with determined cutoff points. Thirty questions have been designed for each age group, 6 questions for each area. The highest achievable score for each question is 10 (60 for each area) and the lowest is 0 . Scores for each area are collected and then compared with cutoff points of that area. Infants with a score lower than cutoff-SD in at least one field are considered to have problems and are admitted to higher levels of the health system. Several studies have demonstrated ASQ as a trustable screening method, even in translated and localized versions (Richter and Janson, 2007; Yu et al., 2007; Kapci et al., 2010). In a study conducted in 18 countries located in Asia, Africa, Europe as well as North and South America in 2007, sensitivity and specificity of this method were measured $88 \%$ and $82.5 \%$, respectively (Altman et al., 2002; Yu et al., 2007).

4. The questionnaire designed by the researcher: it includes demographic information (age, education and occupation of parents), pregnancy information (number of pregnancies, number of deliveries, delivery types and infant sex) and infant physical characteristics (age, weight, sex, height and head circumference).

5. Salivary cortisol and leptin measurement kits: leptin levels were measured using BioVendor kits made in Czech Republic with sensitivity of $0.2 \mathrm{ng} / \mathrm{ml}$ and specificity of $100 \%$. Moreover, cortisol levels were measured using DiaMetra kits made in Italy with sensitivity of $2.44 \mathrm{ng} / \mathrm{ml}$ and specificity of $100 \%$.

\section{Statistical analysis}

All statistical analyses were conducted using IBM SPSS Statistics 23 (SPSS Inc., Chicago, IL, USA) and descriptive analyses and frequency tables were conducted using this application. The KolmogorovSmirnov test was used to determine the normality of distribution. Quantitative variables were reported as mean $\pm S D$ and qualitative data were presented in terms of rates and proportions. The statistical analyses were conducted using t-student and Pearson tests. $P$-value $<0.05$ was considered statistically significant.

\section{Results}

Demographic and reproductive information of participants is showed in Table 1. Among the infants studied, 41 percent was girl. Among the mothers, $21.3 \%$ experienced their first delivery. Finally, $70 \%$ of the mothers had vaginal delivery.

To address the effect of newborn's sex on proposed variables, data related to stress score, leptin and cortisol were compared between boys and girls. Although the leptin levels were higher in girls than boys, there was no significant difference between two sexes on any items. Also, we checked these variables between normal delivery and cesarean section. There was no significant difference between two types of delivery; therefore, all data were 
Table 1: Demographic and reproductive information in research units

\begin{tabular}{|c|c|c|}
\hline Variable & Category & Percent( frequency) \\
\hline Mother's age (year) & $\begin{array}{l}\leq 18 \text { years } \\
19-34 \\
\geq 35\end{array}$ & $\begin{array}{l}7.5(6) \\
78.7(63) \\
13.8(11) \\
\end{array}$ \\
\hline \multirow{3}{*}{ Mother's education } & Elementary & $40(32)$ \\
\hline & Middle school & $42.5(34)$ \\
\hline & Collegiate & $17.5(14)$ \\
\hline \multirow{2}{*}{ Mother's job } & Housewife & $97.5(78)$ \\
\hline & Employed & $2.5(2)$ \\
\hline \multirow{3}{*}{ Father's education } & Elementary & $38.8(31)$ \\
\hline & Middle school & $48.7(39)$ \\
\hline & Collegiate & $12.5(10)$ \\
\hline \multirow{2}{*}{ Father's job } & Unemployed & $10(8)$ \\
\hline & Employed & $90(72)$ \\
\hline \multirow{3}{*}{ Parity } & no & $21.3(17)$ \\
\hline & 1 & $50(40)$ \\
\hline & 2 or more & $28.8(23)$ \\
\hline \multirow{2}{*}{ Newborn sex } & boy & $58.7(47)$ \\
\hline & girl & $41.3(33)$ \\
\hline \multirow{2}{*}{ Type of delivery } & vaginal delivery & $70(56)$ \\
\hline & cesarean section & $30(24)$ \\
\hline
\end{tabular}

combined and analyzed together.

Mean cortisol concentration $(\mathrm{ng} / \mathrm{ml})$ in the cord blood samples at birth $(307.57 \pm 12.56)$ and the saliva samples at 6 months of age $(312.36 \pm 82.43)$ were detected. Also, mean leptin concentration $(\mathrm{ng} / \mathrm{ml})$ in the cord blood at birth and the saliva samples at 6 months of age were $23.23 \pm 10.18$ and $65.77 \pm 77.11$, respectively. We observed a significant relationship between leptin and cortisol levels at 6 months of age ( $r=0.272$ and $P=0.022$ ).

Table 2 demonstrates weight, head circumference and height of the infants at birth and 2, 4 and 6 months after birth. As observed in the Table, 7, 11 and 10 infants had developmental problems at 2, 4 and 6 months of age, respectively. Moreover, the mean PSS of the mothers during pregnancy was 26.85 \pm 2.65 . We observed a significant correlation between maternal PSS and infant weight at 6 months of age $(P=0.012)$. Moreover, the level of saliva cortisol at 6 months of age was significantly correlated with infant height at 2 months after birth $(P=0.034)$. Finally, there was a significant negative association between leptin level at 6 months after birth and infant height at $2(P=0.004), 4 \quad(P=0.001)$ and $6(P=0.001)$ months of birth (Table 3$)$.

There was a negative relationship between infant development at 2 months of age and maternal PSS during pregnancy $(P<0.001)$, but no association was observed between PSS and infant development at 4 $(P=0.509)$ and $6(P=0.747)$ months of age (Table 4). Additionally, cortisol and leptin levels at birth and 6 months after birth were not significantly correlated with infant development at 4 and 6 months of age. Finally, no significant relationship was observed between PSS with cortisol and leptin levels at birth and 6 months after birth.

\section{Discussion}

In the current study, we found a negative correlation between maternal PSS and infant's weight at 6 months of age. In a study conducted by Bazr Afshan and Mahmoodi (2009), they showed that women's anxiety during pregnancy caused low birth weight in offspring. Studies have also shown that women experiencing stress during pregnancy are more likely to have preterm deliveries (Punamäki et al., 2006). It 
Table 2: Descriptive data about growth and development of the infants

\begin{tabular}{|c|c|c|c|c|c|c|c|c|c|c|c|c|c|c|}
\hline \multirow{4}{*}{$\begin{array}{l} \\
\text { Infant growth } \\
\text { criteria } \\
\text { (mean } \pm S D)\end{array}$} & & & \multicolumn{3}{|c|}{ At birth } & \multicolumn{3}{|c|}{$\begin{array}{l}2 \text { months after } \\
\text { birth }\end{array}$} & \multicolumn{3}{|c|}{$\begin{array}{c}4 \text { months after } \\
\text { birth }\end{array}$} & \multicolumn{3}{|c|}{$\begin{array}{c}6 \text { months after } \\
\text { birth }\end{array}$} \\
\hline & \multicolumn{2}{|c|}{ Weight (g) } & \multicolumn{3}{|c|}{$3231.25 \pm 576.89$} & \multicolumn{3}{|c|}{$5216 \pm 736.12$} & \multicolumn{3}{|c|}{$6660 \pm 881.39$} & \multicolumn{3}{|c|}{$7896 \pm 1016.39$} \\
\hline & \multicolumn{2}{|c|}{$\begin{array}{l}\text { Head circumference } \\
(\mathrm{cm})\end{array}$} & \multicolumn{3}{|c|}{$34.42 \pm 2.18$} & \multicolumn{3}{|c|}{$38.31 \pm 1.93$} & \multicolumn{3}{|c|}{$40.60 \pm 1.80$} & \multicolumn{3}{|c|}{$42.45 \pm 1.59$} \\
\hline & \multicolumn{2}{|c|}{ Height $(\mathrm{cm})$} & \multicolumn{3}{|c|}{$50.51 \pm 3.08$} & \multicolumn{3}{|c|}{$56.16 \pm 2.67$} & \multicolumn{3}{|c|}{$61.85 \pm 2.59$} & \multicolumn{3}{|c|}{$67.33 \pm 2.56$} \\
\hline \multirow{5}{*}{$\begin{array}{l}\text { Infant } \\
\text { development } \\
\text { criteria: } \\
\text { (absolute } \\
\text { and relative } \\
\text { frequency) }\end{array}$} & \multicolumn{2}{|c|}{2 months after birth } & \multicolumn{6}{|c|}{4 months after birth } & \multicolumn{6}{|c|}{6 months after birth } \\
\hline & $\begin{array}{l}\text { With } \\
\text { problems }\end{array}$ & $\begin{array}{l}\text { Without } \\
\text { problems }\end{array}$ & \multicolumn{5}{|c|}{ With problems } & \multirow[b]{2}{*}{ 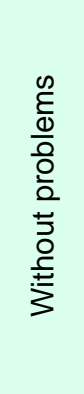 } & \multicolumn{5}{|c|}{ With problems } & \multirow{2}{*}{ 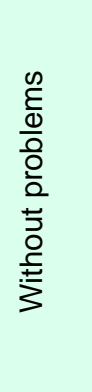 } \\
\hline & & & 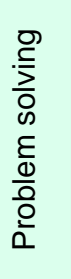 & 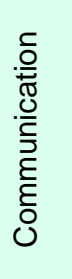 & 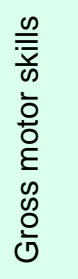 & 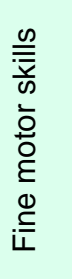 & $\begin{array}{l}\overline{\bar{\sigma}} \\
\frac{0}{0} \\
\frac{0}{1} \\
\frac{1}{\pi} \\
\overline{0} \\
\frac{0}{0} \\
\frac{\omega}{0} \\
0\end{array}$ & & 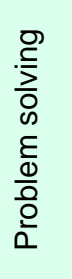 & 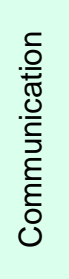 & 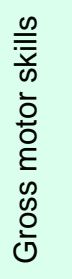 & 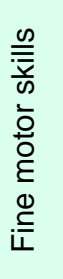 & 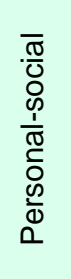 & \\
\hline & 7 & 73 & 3 & 2 & 1 & 2 & 3 & 69 & 3 & 1 & 2 & 1 & 3 & 70 \\
\hline & 8.7 & 91.3 & 3.8 & 2.5 & 1.3 & 2.5 & 3.8 & 86.3 & 3.8 & 1.3 & 2.5 & 1.3 & 3.8 & 87.5 \\
\hline
\end{tabular}

The values related to infant growth criteria are mean \pm SD

was reported that PSS negatively correlated with birth weight, height and head circumference (Shayeghian and Tabatabaey, 2008) which can be partly resulted from low uterine blood supply due to stress-induced vasoconstriction (Osol and Mandala, 2009). This finding supports the results of our study. According to the findings of the current and some other studies, it can be inferred that stress during pregnancy might negatively affect infant growth (Ebrahimi et al., 2014; Heshmatian et al., 2010) and infants with growth problems could face growth retardation in different life stages (Kammerer et al., 2002; Robertson et al., 2004). Thus, although we observed no significant relationship between mother PSS during pregnancy with offspring height and head circumference in different life stages, our findings demonstrated that there was a negative correlation between PSS and growth criteria, which is in agreement with the findings of other studies.

According to our findings, there was a negative association between maternal PSS during pregnancy and offspring development at 2 months after birth. Studies have suggested that mothers experiencing stress during pregnancy may have offspring with delayed walking and speech, learning and memory deficits, sleep disorders and excitability, somatic disorders, increased excitatory reactions and seizure susceptibility, low mood and behavioral and affective disorders (Kapoor et al., 2009; Glover, 2015). It is clear that the growth and behavior of the offspring can be altered by PS. Maternal stress exerts intense influences on offspring's development inducing abnormalities which extend from early to later life (Maccari et al., 2003). Therefore, our result, maternal PSS affected infant development after 6 month, is consistent with exiting literature. These short- and long-term consequences, at least in part, arise from some proven events: excess circulating maternal stress hormones alter the programming of fetal brain (HPA axis and others) and together with genetic factors, the postnatal environment and quality of maternal attention, express the growth, development and behavior of the offspring (Weinstock, 2008).

In addition to PS, stress during postnatal period has also been observed to cause some of the mentioned disorders such as increased risk of epilepsy at older ages (Galic et al., 2008; Gholipoor et al., 2013). Thus, pre and postnatal stresses have been suggested to play a key role in etiology of many childhood and adulthood disorders. As most of the studies are mainly focused on the effects of PS on offspring development, we suggest further studies to assess the impacts of postnatal, particularly early postnatal stress on neurodevelopment of offspring. Studies have shown that stress during late pregnancy is associated with lower cognitive development at 2 
Table 3: Assessing correlation of infant growth with maternal perceived stress score (PSS) and infant cortisol and leptin levels

\begin{tabular}{|c|c|c|c|c|c|c|c|c|c|c|c|c|}
\hline$\frac{0}{\frac{0}{0}}$ & \multicolumn{4}{|c|}{ Weight } & \multicolumn{4}{|c|}{ Height } & \multicolumn{4}{|c|}{ Head circumference } \\
\hline age & At birth & $\begin{array}{c}2 \\
\text { months }\end{array}$ & $\begin{array}{c}4 \\
\text { months }\end{array}$ & $\begin{array}{c}6 \\
\text { months }\end{array}$ & $\begin{array}{c}\text { At } \\
\text { birth }\end{array}$ & $\begin{array}{c}2 \\
\text { months }\end{array}$ & $\begin{array}{c}4 \\
\text { months }\end{array}$ & $\begin{array}{c}6 \\
\text { months }\end{array}$ & $\begin{array}{c}\text { At } \\
\text { birth }\end{array}$ & $\begin{array}{c}2 \\
\text { months }\end{array}$ & $\begin{array}{c}4 \\
\text { months }\end{array}$ & $\begin{array}{c}6 \\
\text { months }\end{array}$ \\
\hline 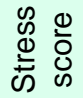 & $\begin{array}{l}P=.92 \\
r=.01\end{array}$ & $\begin{array}{l}0.28 \\
-.12\end{array}$ & $\begin{array}{l}.096 \\
-.19\end{array}$ & $\begin{array}{l}.012^{*} \\
-0.28\end{array}$ & $\begin{array}{l}.48 \\
-.07\end{array}$ & $\begin{array}{l}.76 \\
-.03\end{array}$ & $\begin{array}{l}.96 \\
-.01\end{array}$ & $\begin{array}{l}.83 \\
-.02\end{array}$ & $\begin{array}{c}.91 \\
-0.12\end{array}$ & $\begin{array}{l}.73 \\
.038\end{array}$ & $\begin{array}{c}.67 \\
-0.04\end{array}$ & $\begin{array}{l}.41 \\
-.93\end{array}$ \\
\hline 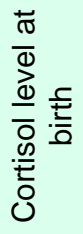 & $\begin{array}{l}P=.08 \\
r=.44\end{array}$ & $\begin{array}{l}.38 \\
.09\end{array}$ & $\begin{array}{l}.07 \\
.20\end{array}$ & $\begin{array}{l}.22 \\
.14\end{array}$ & $\begin{array}{l}.82 \\
.02\end{array}$ & $\begin{array}{l}.76 \\
-.03\end{array}$ & $\begin{array}{l}.21 \\
.14\end{array}$ & $\begin{array}{l}.19 \\
.14\end{array}$ & $\begin{array}{l}.11 \\
.324\end{array}$ & $\begin{array}{l}.31 \\
-.12\end{array}$ & $\begin{array}{c}.50 \\
-0.07\end{array}$ & $\begin{array}{l}.45 \\
-.08\end{array}$ \\
\hline 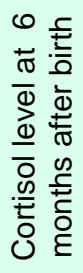 & $\begin{array}{l}P=.25 \\
r=.10\end{array}$ & $\begin{array}{l}.064 \\
-.22\end{array}$ & $\begin{array}{l}.093 \\
-.20\end{array}$ & $\begin{array}{l}.23 \\
-.14\end{array}$ & $\begin{array}{l}.359 \\
-.11\end{array}$ & $\begin{array}{l}.034^{*} \\
-.25\end{array}$ & $\begin{array}{l}.826 \\
.026\end{array}$ & $\begin{array}{l}.733 \\
.014\end{array}$ & $\begin{array}{l}.121 \\
.184\end{array}$ & $\begin{array}{l}.59 \\
.065\end{array}$ & $\begin{array}{l}.77 \\
.035\end{array}$ & $\begin{array}{c}.88 \\
-.018\end{array}$ \\
\hline 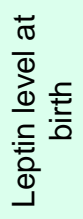 & $\begin{array}{l}P=.89 \\
r=-.02\end{array}$ & $\begin{array}{l}.61 \\
.05\end{array}$ & $\begin{array}{l}.08 \\
-.03\end{array}$ & $\begin{array}{l}.68 \\
-.05\end{array}$ & $\begin{array}{l}.317 \\
.11\end{array}$ & $\begin{array}{l}.36 \\
.10\end{array}$ & $\begin{array}{l}.82 \\
-.02\end{array}$ & $\begin{array}{l}.50 \\
-.07\end{array}$ & $\begin{array}{l}.94 \\
.01\end{array}$ & $\begin{array}{l}.56 \\
.06\end{array}$ & $\begin{array}{l}.23 \\
.14\end{array}$ & $\begin{array}{l}.12 \\
.17\end{array}$ \\
\hline 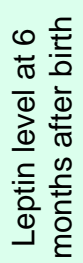 & $\begin{array}{l}P=.65 \\
r=-.05\end{array}$ & $\begin{array}{l}.71 \\
.04\end{array}$ & $\begin{array}{l}.89 \\
.02\end{array}$ & $\begin{array}{l}.42 \\
.09\end{array}$ & $\begin{array}{l}.24 \\
-.14\end{array}$ & $\begin{array}{l}.004^{*} \\
-.33\end{array}$ & $\begin{array}{l}.001^{*} \\
-.38\end{array}$ & $\begin{array}{l}.001^{*} \\
-.39\end{array}$ & $\begin{array}{l}.39 \\
-.12\end{array}$ & $\begin{array}{l}0.8 \\
-.03\end{array}$ & $\begin{array}{l}.49 \\
-.08\end{array}$ & $\begin{array}{l}.398 \\
-.10\end{array}$ \\
\hline
\end{tabular}

indicates significant correlation and the related $P$-value in each case

years of age. Additionally, stress induces preterm labor which also causes low weight and inappropriate growth of offspring. The infants of stressed mothers are more prone to experience physical and cognitive disorders such as cerebral palsy and learning deficits (Kammerer et al., 2002; Robertson et al., 2004). Although we observed no significant association between maternal PSS and child development at 4 and 6 months of age, our findings support the results of the mentioned studies. This discrepancy may be resulted from using ASQ which is filled out according to parents' expressions and any inaccurate answers from parents could affect the results.

The findings of the current study suggested significant negative correlations between cortisol level at 6 months and height at 2 months of age and also between leptin level at 6 months and height at 2, 4 and 6 months of age. Leptin is considered as an antiobesity hormone which reduces food intake through its receptors in hypothalamus. It also regulates bone growth and functioning of the immune system. According to studies, leptin level in fetus correlates with birth weight which shows the significance of leptin in fetal growth and development (Briffa et al., 
Table 4: Correlation of infant development with maternal perceived stress score (PSS), infant cortisol and leptin levels in cord blood (at birth) and saliva (at 6 months after birth)

\begin{tabular}{|c|c|c|c|c|c|c|}
\hline & & $\begin{array}{c}\text { Maternal } \\
\text { perceived stress } \\
\text { score }\end{array}$ & $\begin{array}{l}\text { Cortisol level } \\
\text { at birth }\end{array}$ & $\begin{array}{c}\text { Cortisol level } 6 \\
\text { months after } \\
\text { birth }\end{array}$ & $\begin{array}{l}\text { Leptin level } \\
\text { at birth }\end{array}$ & $\begin{array}{c}\text { Leptin level } 6 \\
\text { months after } \\
\text { birth }\end{array}$ \\
\hline \multirow{3}{*}{$\begin{array}{l}\text { Infant } \\
\text { development } \\
\text { criteria ( } p \text { and } r \text { ) }\end{array}$} & $\begin{array}{l}2 \text { months } \\
\text { after birth }\end{array}$ & $\begin{array}{c}P<0.001^{*} \\
r=-0.26\end{array}$ & $\begin{array}{l}0.242 \\
0.132\end{array}$ & $\begin{array}{l}0.385 \\
0.104\end{array}$ & $\begin{array}{l}0.054 \\
0.216\end{array}$ & $\begin{array}{l}0.286 \\
-0.28\end{array}$ \\
\hline & $\begin{array}{l}4 \text { months } \\
\text { after birth }\end{array}$ & $\begin{array}{l}P=0.509 \\
r=0.075\end{array}$ & $\begin{array}{l}0.115 \\
0.178\end{array}$ & $\begin{array}{l}0.217 \\
-0.147\end{array}$ & $\begin{array}{l}0.306 \\
-0.116\end{array}$ & $\begin{array}{l}0.623 \\
-0.059\end{array}$ \\
\hline & $\begin{array}{l}6 \text { months } \\
\text { after birth }\end{array}$ & $\begin{array}{l}P=0.747 \\
r=-0.037\end{array}$ & $\begin{array}{l}0.419 \\
0.092\end{array}$ & $\begin{array}{l}0.152 \\
0.138\end{array}$ & $\begin{array}{l}0.964 \\
0.005\end{array}$ & $\begin{array}{l}0.105 \\
0.183\end{array}$ \\
\hline
\end{tabular}

indicates significant correlation and the related $P$-value

2015). In a study, negative correlation between leptin and growth hormone has been reported. The growth hormone treatment was accompanied by decreased serum levels of leptin by a mean of $-24 \%$ (Eden Engstrom et al., 2003). Also, leptin levels in patients with acromegaly are significantly lower than those in normal subjects (Isozaki et al., 1999). However, it has been reported that leptin pretreatment of pituitary cells in culture or rats does not change growth hormone secretion (Isozaki et al., 1999). Conversely, leptin stimulates linear growth by stimulating the production and secretion of growth hormone from the hypothalamus; simultaneously, it has a direct effect on the chondrocytes in epiphyseal plate and involved with bone remodeling (Gat-Yablonski and Phillip, 2008). In the context of these discrepancies, we assume that, in the current study, higher levels of leptin might accompany by lower levels of growth hormone or other growth factors such as IGF1, which led to shorter height in these infants, or simply it might be an experimental mistake of unknown origin and future studies may confirm the result.

In the current study, we observed a significant relationship between leptin and cortisol levels at 6 months of age which might be due to the effects of glucocorticoids on leptin synthesis and secretion. Leptin is also able to affect adrenal gland functions; specifically, the HPA axis, in harmony with the leptin, establishes a basic brain-body feedback loop, which empowers the central nervous system to sense and regulate peripheral fat stores, energy homeostasis and feeding behaviors, but the exact mechanism is almost unknown (Aschbacher et al., 2014). There is controversy over the effects of HPA axis on leptin secretion (Nishii et al., 2006). Studies suggested that due to decreased glucocorticoid receptors in hypothalamus, particularly in periventricular nucleus, the negative feedback for corticotropin-releasing hormone was weakened and a plasma level of cortisol (human) and corticosterone (rats and mice) was elevated in subjects experiencing PS (Gholipoor et al., 2017). Thus, these subjects might face problems in adaptation to the environment (Weinstock, 2015). Edward et al. (2002) also carried out a study to assess the effects of stress during pregnancy on changes of behavioral and hormonal responses which are involved in regulation of body weight such as increased appetite and combination of metabolic syndromes including insulin resistance and increased serum levels of cortisol and leptin. They concluded that fat tissues played a role in response to stress by secreting leptin. Thus, it can be inferred that due to significant correlation between cortisol and leptin levels, increased cortisol level as a stress hormone stimulates leptin secretion and has adverse effects on offspring growth.

In the current study, the effect of PS was evaluated on offspring growth and development from 24 weeks of pregnancy up to 6 months after birth. As this was the first longitudinal study examining these effects in the Iranian society, we recommend further longitudinal studies in this field with higher sample sizes in various statistical populations with checking mother's body mass index (BMI) which was not checked in the current study.

\section{Conclusion}

In conclusion, we observed that PSS significantly correlated with offspring growth and development. Leptin appears to play a key role in growth and 
development, which may adversely affect the risk of developing a number of diseases in adulthood. Although further studies are required in this field, we conclude that due to changes in cortisol and leptin levels at birth and 6 months after birth and their correlation with offspring growth and development, these hormones can probably be appropriate biomarkers for prediction and diagnosis of offspring growth and developmental disorders in context of stress. Thus, better understanding of the role of leptin during development can assist in the prevention and treatment of a number of disease states that occur later in life.

\section{Acknowledgments}

This study was financially supported by Urmia University of Medical Sciences, Urmia, Iran. We thank the staff of Fatemeh Zahra Hospital and health centers of Miandoab, West Azerbaijan Province, Iran.

\section{Conflict of interest}

Authors declare no conflict of interest regarding this paper.

\section{References}

Abedi M, Sboory E, Rabiepour S, Rasouli J. The relationship between stress in pregnancy and pregnancy outcomes: A longitudinal study. J Urmia Nurs Midwifery Fac 2017; 14: 969-981.

Adam EK, Kumari M. Assessing salivary cortisol in largescale, epidemiological research. Psychoneuro endocrinology 2009; 34: 1423-36. DOI: 10.1016/ j.psyneuen.2009.06.011

Alpers GW, Abelson JL, Wilhelm FH, Roth WT. Salivary cortisol response during exposure treatment in driving phobics. Psychosom Med 2003; 65: 679-87. DOI:10.1097/01.psy.0000073872.85623.0c

Altman D, Carroli G, Duley L, Farrell B, Moodley J, Neilson $J$, et al. Do women with pre-eclampsia, and their babies, benefit from magnesium sulphate? The magpie trial: a randomised placebo-controlled trial. Lancet 2002; 359: 1877-90. DOI:10.1016/s0140-6736(02)08778-0

Aschbacher K, Rodriguez-Fernandez M, van Wietmarschen $H$, Tomiyama AJ, Jain $S$, Epel $E$, et al. The hypothalamic-pituitary-adrenal-leptin axis and metabolic health: a systems approach to resilience, robustness and control. Interface Focus 2014; 4: 20140020. DOI: 10.1098/rsfs.2014.0020

Bazr Afshan M, Mahmoodi Rad A. The relationship between women's anxiety during pregnancy and labor outcomes in larestan hospitals. Mandish 2009; 1: 1-12.

Black RE, Victora CG, Walker SP, Bhutta ZA, Christian P, de Onis $M$, et al. Maternal and child undernutrition and overweight in low-income and middle-income countries.
Lancet 2013; 382: 427-451. DOI: 10.1016/S01406736(13)60937-X

Briffa JF, McAinch AJ, Romano T, Wlodek ME, Hryciw DH. Leptin in pregnancy and development: a contributor to adulthood disease? Am J Physiol Endocrinol Metab 2015; 308: E335-50. DOI: 10.1152/ajpendo.00312.2014

Bronson SL, Bale TL. The placenta as a mediator of stress effects on neurodevelopmental reprogramming. Neuropsychopharmacology 2016; 41: 207-18. DOI: 10.1038/npp.2015.231

Cohen S, Kamarck T, Mermelstein R. A global measure of perceived stress. J Health Soc Behav 1983; 24: 385-96. DOI:http://dx.doi.org/10.13072/midss.461

Cookson H, Granell R, Joinson C, Ben-Shlomo Y, Henderson AJ. Mothers' anxiety during pregnancy is associated with asthma in their children. J Allergy Clin Immunol 2009; 123: 847-53. DOI: 10.1016/j.jaci. 2009.01.042

Ebrahimi L, Saboory E, Roshan-Milani S, Hashemi P. Effect of prenatal forced-swim stress and morphine coadministration on pentylentetrazol-induced epileptic behaviors in infant and prepubertal rats. Dev Psychobiol 2014; 56: 1179-86. DOI: 10.1002/dev.21198. Epub 2014 Jan 24

Eden Engstrom B, Burman P, Holdstock C, Karlsson FA. Effects of growth hormone $(\mathrm{GH})$ on ghrelin, leptin, and adiponectin in $\mathrm{GH}$-deficient patients. J Clin Endocrinol Metab 2003; 88: 5193-8. DOI: 10.1210/jc.2003-030713

Edwards HE, Dortok D, Tam J, Won D, Burnham WM. Prenatal stress alters seizure thresholds and the development of kindled seizures in infant and adult rats. Horm Behav 2002; 42: 437-47. DOI: 10.1006/ hbeh.2002.1839

Eftekhari MH, Ranjbar-Zahedani M, Basiratnia $M$, Rezaianzadeh A, Faghih S. Comparison of appetiteregulating hormones and body composition in pediatric patients in predialysis stage of chronic kidney disease and healthy control group. Iran J Med Sci 2015; 40: 27 33.

Galic MA, Riazi K, Heida JG, Mouihate A, Fournier NM, Spencer SJ, et al. Postnatal inflammation increases seizure susceptibility in adult rats. J Neurosci 2008; 28: 6904-13. DOI: 10.1523/JNEUROSCI.1901-08.2008

Gat-Yablonski G, Phillip M. Leptin and regulation of linear growth. Curr Opin Clin Nutr Metab Care 2008; 11: 3038. DOI: 10.1097/MCO.0b013e3282f795cf

Gholipoor P, Saboory E, Ghazavi A, Kiyani A, RoshanMilani S, Mohammadi S, et al. Prenatal stress potentiates febrile seizure and leads to long-lasting increase in cortisol blood levels in children under 2 years old. Epilepsy Behav 2017; 72: 22-27. doi: 10.1016/j.yebeh.2017.04.021

Gholipoor P, Saboory E, Roshan-Milani S, Fereidoni J. Effect of hyperthermia on histamine blood level and convulsive behavior in infant rats. Epilepsy Behav 2013; 29: 269-74. DOI: 10.1016/j.yebeh.2013.07.026

Glover V. Prenatal stress and its effects on the fetus and the child: possible underlying biological mechanisms. Adv Neurobiol 2015; 10: 269-83. DOI: 10.1007/978-1- 
4939-1372-5 13

Heshmatian B, Roshan-Milani S, Saboory E. Prenatal acute stress attenuated epileptiform activities in neonate mice. Yakhteh 2010; 12: 81-86+124. DOI: 10.22074/cellj. 2010.3778

Hosseini-Sharifabad M, Sabahi A. Stereological estimation of granule cell number and purkinje cell volume in the cerebellum of noise-exposed young rat. Iran J Med Sci 2014; 39: 387-90.

Isozaki O, Tsushima T, Miyakawa M, Demura $\mathrm{H}$, Seki $\mathrm{H}$. Interaction between leptin and growth hormone (GH)/IGF-I axis. Endocr J 1999; 46 Suppl: S17-24. DOI:10.1507/endocrj.46.suppl_s17

Kammerer M, Adams D, Von Castelberg B, Glover V. Pregnant women become insensitive to cold stress. BMC pregnancy childbirth 2002; 2: 8. DOI: 10.1186/ 1471-2393-2-8

Kapci EG, Kucuker S, Uslu RI. How applicable are ages and stages questionnaires for use with turkish children? Topics Early Child Spec Educ 2010; 30: 176-188. DOI: 10.1177/0271121410373149

Kapoor A, Kostaki A, Janus C, Matthews SG. The effects of prenatal stress on learning in adult offspring is dependent on the timing of the stressor. Behav Brain Res 2009; 197: 144-9. DOI: 10.1016/j.bbr.2008.08.018

Kudielka BM, Buske-Kirschbaum A, Hellhammer D, Kirschbaum C. Hpa axis responses to laboratory psychosocial stress in healthy elderly adults, younger adults, and children: impact of age and gender. Psychoneuroendocrinology 2004; 29: 83-98. DOI:10. 1016/s0306-4530(02)00146-4

Lee MJ, Wang Y, Ricci MR, Sullivan S, Russell CD, Fried SK. Acute and chronic regulation of leptin synthesis, storage, and secretion by insulin and dexamethasone in human adipose tissue. Am J Physiol Endocrinol Metab 2007; 292: E858-64. DOI: 10.1152/ajpendo.00439.2006

Maccari S, Darnaudery M, Morley-Fletcher S, Zuena AR, Cinque C, Van Reeth O. Prenatal stress and long-term consequences: implications of glucocorticoid hormones. Neurosci Biobehav Rev 2003; 27: 119-27. DOI:10.1016/ s0149-7634(03)00014-9

Nishii N, Takasu M, Ohba Y, Maeda S, Kitoh K, Ohtsuka Y, et al. Effects of administration of glucocorticoids and feeding status on plasma leptin concentrations in dogs. Am J Vet Res 2006; 67: 266-70. DOI: 10.2460/ajvr.67. 2.266

Oates MR. Adverse effects of maternal antenatal anxiety on children: causal effect or developmental continuum? $\mathrm{Br}$ J Psychiatry 2002; 180: 478-9. DOI:10.1192/bjp.180. 6.478

Osol G, Mandala M. Maternal uterine vascular remodeling during pregnancy. Physiology (Bethesda) 2009; 24: 5871. DOI: $10.1152 /$ physiol.00033.2008

Punamäki RL, Repokari L, Vilska S, Poikkeus P, Tiitinen A, Sinkkonen J, et al. Maternal mental health and medical predictors of infant developmental and health problems from pregnancy to one year: Does former infertility matter? Infant Behav Dev 2006; 29: 230-42. DOI: 10.1016/j.infbeh.2005.12.001

Richter J, Janson H. A validation study of the Norwegian version of the Ages and Stages Questionnaires. Acta Paediatrica 2007; 96: 748-52. DOI: 10.1111/j.16512227.2007.00246.x

Robertson E, Grace S, Wallington T, Stewart DE. Antenatal risk factors for postpartum depression: a synthesis of recent literature. Gen Hosp Psychiatry 2004; 26: 28995. DOI: 10.1016/j.genhosppsych.2004.02.006

Saboory E, Mohammadi S, Dindarian S, Mohammadi H. Prenatal stress and elevated seizure susceptibility: molecular inheritable changes. Epilepsy Behav 2019; 96: 122-131. DOI: 10.1016/j.yebeh.2019.04.046

Salari P, Alavian F, Habibi Rad A, Tara F. The relationship between stress, anxiety and pain with salivary cortisol levels in first stage of labor in primiparous women. Iran J Obstet Gynecol Infertil 2013; 16: 14-21.

Shayeghian Z, Tabatabaey S. Effect of maternal anxiety during third trimester on pregnancy outcomes and infants' mental health. Hayat 2009;14: 57-65.

Taddio A, Katz J. The effects of early pain experience in neonates on pain responses in infancy and childhood. Paediatr Drugs 2005; 7: 245-57. DOI: 10.2165/ 00148581-200507040-00004

Van den Bergh BR, Mennes M, Oosterlaan J, Stevens V, Stiers P, Marcoen A, et al. High antenatal maternal anxiety is related to impulsivity during performance on cognitive tasks in 14-and 15-year-olds. Neurosci Biobehav Rev 2005; 29: 259-69. DOI:10.1016/ j.neubiorev.2004.10.010

Vedhara K, Miles J, Bennett P, Plummer S, Tallon D, Brooks $E$, et al. An investigation into the relationship between salivary cortisol, stress, anxiety and depression. Biol Psychol 2003; 62: 89-96. DOI: 10.1016/s0301-0511(02)00128-x

Weinstock $M$. The long-term behavioural consequences of prenatal stress. Neurosci Biobehav Rev 2008; 32: 107386. DOI: 10.1016/j.neubiorev.2008.03.002

Weinstock $M$. Changes induced by prenatal stress in behavior and brain morphology: can they be prevented or reversed? Perinatal programming of neurodevelopment: Adv Neurobiol. 2015;10:3-25. DOI: 10.1007/978-1-4939-1372-5_1.

Woods SM, Melville JL, Guo Y, Fan MY, Gavin A. Psychosocial stress during pregnancy. Am J Obstet Gynecol 2010; 202: 61. e1-61. e7. DOI: 10.1016/ j.ajog.2009.07.041

Yu LM, Hey E, Doyle LW, Farrell B, Spark P, Altman DG, et al. Evaluation of the ages and stages questionnaires in identifying children with neurosensory disability in the magpie trial follow-up study. Acta paediatr 2007; 96: 1803-8. DOI: 10.1111/j.1651-2227.2007.00517.x

Zijlmans MA, Beijers R, Mack S, Pruessner JC, de Weerth C. Cortisol responses to social evaluation in 10-to 15year-old boys and girls. Stress 2013; 16: 393-401. DOI: $10.3109 / 10253890.2013 .76449$ 